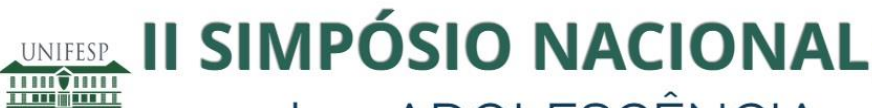 sobre ADOLESCÊNCIA: Vulnerabilidades, Protagonismos e Desafios
}

\section{Análise das características pedagógicas de animações longa metragem com indicação livre}

\author{
Fernanda Regina Pires \\ Universidade Federal De São Paulo \\ E-mail:fr_pires@hotmail.com
}

Denise de Micheli

\begin{abstract}
Como citar:
PIRES, Fernanda Regina; MICHELI, Denise de. Análise das características pedagógicas de animações longa metragem com indicação livre. In: SIMPÓSIO NACIONAL SOBRE ADOLESCÊNCIA: VULNERABILIDADE, PROTAGONISMOS E DESAFIOS, 2, 2016, São Paulo. Anais...[S. I.]: 2016. p. 47-48. DOI: http://dx.doi.org/10.22388/2525-5894.2016.026
\end{abstract}

Introdução: nas grandes cidades uma das opções de lazer é o cinema. Pessoas de todas as idades apreciam esta forma de arte, além de promover o entretenimento pode educar e estimular a reflexão sobre diversos assuntos. Um dos tipos de atrações que encontra-se nos cinemas são os filmes de animação longa metragem. Esses filmes têm ganhado bastante espaço, já que a cada ano cresce o número de estreias de filmes infantis. Por esse motivo, o objetivo da presente pesquisa foi analisar as características pedagógicas de animações longa metragem com indicação livre. Para isso foi realizada uma pesquisa de caráter qualitativo, em que não é permitido fazer generalizações, todos os dados são analisados, se necessário, isoladamente para entender e discutir os processos que estão envolvidos. (PATTON, 2002). Foi realizada a análise documental de 40 animações longa metragem de classificação indicativa livre, lançados de 2011 à 2016. Os filmes foram selecionados de maneira aleatória. Os filmes foram assistidos e um roteiro com 12 itens para identificação das características pedagógicas foi preenchido para posterior análise. Os filmes apresentaram características semelhantes ao que se refere à produção. Todos eles possuem cenas e/ou personagens engraçados e músicas que estimulam e alegram os espectadores. Existe um apelo ao marketing de quase todos que, envolvem o público não só com o filme em si mas, com produtos diversos: roupas, brinquedos, calçados etc. Com relação aos aspectos pedagógicos foi observado através das análises que ao longo dos anos, ou seja, os filmes mais atuais, buscam transmitir uma mensagem educativa e/ ou que estimule a reflexão de assuntos atuais como: preconceito, família, obesidade, depressão, drogas, abuso de poder, entre outros. No entanto, alguns filmes ainda apresentam situações contrárias e com conteúdo pedagógico contestável como: violência, diálogos agressivos, bullying, entre outros. Em ambas as situações, os filmes podem auxiliar as crianças, famílias e escola na abordagem de temas importantes que permeiam a sociedade, desde que haja uma proposta de discussão dirigida dos mesmos. Dessa forma, embora estes filmes sejam de classificação indicativa livre é importante que os pais, responsável e/ou a escola tenham 
atenção para os conteúdos destes filmes e incentivem o diálogo e a reflexão sobre os temas propostos. Contudo, pode-se concluir que os filmes de animação de longa metragem de classificação indicativa livre, em sua maioria, possuem conteúdos pedagógicos positivos, no entanto é necessária a supervisão e o estimulo a discussão por parte de pais e/ou responsáveis e a escola.

Palavras-chaves: Animações. Aspectos pedagógicos. Filmes infantis. 